\title{
PERBANDINGAN KUNJUNGAN PASIEN PER KASUS DI PELAYANAN KESEHATAN GIGI LANJUTAN PADA RUMAH SAKIT DI KOTA PADANG DITINJAU DARI PEMANFAATAN SISTEM JAMINAN KESEHATAN NASIONAL (JKN)
}

\author{
Diva Indah Pratiwi ${ }^{1}$, Rima Semiarty ${ }^{2}$, AriaFransiska ${ }^{3}$ \\ ${ }^{1}$ Faculty of Dentistry Andalas University \\ ${ }^{2}$ Faculty of Medicine Andalas University \\ ${ }^{3}$ Departemen of Dental Public Health Faculty of Dentristry Andalas University
}

\begin{abstract}
Implementation of the National Health Insurance (JKN) in Padang's Hospital has started since 1 January 2014. In practice JKN implement tiered referral system of first-level health facilities to advanced-level health facilities to meet the needs of the patient. This study aimed to compare the level of patient visits before and after JKN and to determine the causes of the referral hospital, especially in Yos Sudarso Padang Hospital and dr. Rasidin Regional Public Hospital Padang.This research is a qualitative descriptive study. Data collection was done by taking the primary data from hospitals and depth interviews with dentists and patients at first-level health facilities and advanced. Data processing is done by reducing the data, presentation of data, drawing conclusions, and analysis of data.The results showed that the level of patient visits Yos Sudarso Padang Hospital increased while at the dr. Rasidin Regional Public Hospital Padang decreased. Level visits patients in Yos Sudarso Padang Hospital increased due to the lack of expertise and infrastructure at the first level of health care. While at dr. Rasidin Regional Public Hospital Padang level of patient visits decreased due to distant location of the hospital and the lack of transportation to the hospital.JKN implementation has been running quite optimal, but still there are patients who complain of difficulty in obtaining health services, especially in the first-level health facilities.
\end{abstract}

Keywords:Patient's case visits, Padang's hospital, JKN

Affiliasi penulis : 1. Fakultas Kedokteran Gigi

Universitas Andalas, 2. Fakultas Kedokteran

Universitas Andalas

Korespondensi : Diva Indah Pratiwi,email:

ddip1710@gmail.com,Telp:082174560993

\section{PENDAHULUAN}

Pelayanan kesehatan adalah hak azazi yang harus didapat oleh setiap manusia yang diakui oleh seluruh bangsa di dunia, termasuk Indonesia. Hal ini tercantum di dalam deklarasi Perserikatan Bangsa - Bangsa tentang Hak Azazi Manusia yang dideklarasikan pada tanggal 10 Desember 1948. Pada Pasal 25 Ayat (1) dinyatakan bahwa setiap orang berhak atas tingkat hidup yang memadai untuk kesehatan dan kesejahteraan dirinya dan keluarganya, termasuk hak atas pangan, pakaian, perumahan dan perawatan kesehatan serta pelayanan sosial yang diperlukan, dan berhak atas jaminan pada saat menganggur, menderita sakit, cacat, menjadi janda/duda, mencapai usia lanjut atau keadaan lainnya yang mengakibatkan kekurangan nafkah, yang berada diluar kekuasaannya. ${ }^{1}$

Atas dasar deklarasi tersebut, beberapa negara mengambil inisiatif 
untuk mengembangkan sistem dan mekanisme pelayanan kesehatan agar mudah didapat dan dijangkau oleh masyarakat, serta mengembangkan sistem jaminan kesehatan agar layanan kesehatan murah didapat bagi semua penduduknya. Pada sidang World Health Assembly (WHA) ke-58 pada tahun 2005 di Jenewa, ditegaskan agar setiap negara anggota memberikan akses terhadap pelayanan kesehatan kepada seluruh masyarakat terutama kepada masyarakat yang kurang mampu dengan menggunakan mekanisme asuransi kesehatan sosial. ${ }^{2}$ Di Indonesia, pelayanan kesehatan bagi masyarakat diatur di dalam UU No. 36 Tahun 2009 tentang Kesehatan yang menyatakan bahwa setiap warga negara memiliki hak yang sama dalam memperoleh akses di bidang kesehatan dan memperoleh pelayanan kesehatan yang aman, bermutu dan terjangkau. ${ }^{3}$ Untuk menjamin terpenuhinya pelayanan kesehatan secara menyeluruh, pada tahun 1982 Indonesia telah menetapkan Sistem Kesehatan Nasional (SKN). SKN adalah pengelolaan kesehatan yang diselenggarakan oleh semua komponen bangsa

Indonesia secara terpadu dan saling mendukung guna menjamin tercapainya derajat kesehatan masyarakat yang setinggi - tingginya. SKN bertujuan untuk menjadi acuan dalam penyusunan dan pelaksanaan pembangunan kesehatan yang dimulai dari kegiatan perencanaan sampai dengan kegiatan monitoring dan evaluasi. Selain itu, SKN juga bertujuan agar terselenggaranya pembangunan kesehatan oleh semua komponen bangsa, baik Pemerintah Pusat, Pemerintah Daerah, dan/atau masyarakat termasuk badan hukum, badan usaha, dan lembaga swasta secara sinergis, berhasil guna dan berdaya guna, sehingga terwujud derajat kesehatan masyarakat yang setinggi tingginya. $^{4}$

Untuk mencapai tujuan tersebut, pemerintah berkewajiban untuk mengadakan Jaminan Kesehatan Nasional (JKN) untuk menjamin kesehatan warga negaranya. JKN adalah jaminan berupa perlindungan kesehatan agar peserta memperoleh manfaat pemeliharaan kesehatan dan perlindungan dalam memenuhi kebutuhan dasar kesehatan yang diberikan kepada setiap orang yang telah membayar iuran atau iurannya dibayar oleh pemerintah.5 JKN yang dikembangkan di Indonesia saat ini merupakan bagian dari Sistem Jaminan Sosial Nasional (SJSN) yang diselenggarakan melalui mekanisme Asuransi Kesehatan Sosial yang bersifat wajib berdasarkan Undang - Undang 
No.40 Tahun 2004 tentang Sistem Jaminan Sosial Nasional. SJSN ini merupakan tata cara penyelenggaraan program jaminan sosial yang diadakan oleh Badan Penyelenggara Jaminan Sosial (BPJS). Tujuannya adalah agar semua penduduk Indonesia terlindungi dalam sistem asuransi, sehingga mereka dapat memenuhi kebutuhan dasar kesehatan masyarakat yang layak.6 Maka sejak tanggal 1 Januari 2014 pemerintah mulai memberlakukan JKN secara merata di seluruh Indonesia termasuk di 17 Kabupaten/Kota di Provinsi Sumatera Barat. Langkah langkah Provinsi Sumatera Barat dalam melaksanakan JKN terlihat dari kesiapan fasilitas pelayanan kesehatan primer yaitu 262 Puskesmas, 142 Klinik Pratama, 955 dokter umum, 236 dokter gigi dan 1.291 bidan serta fasilitas pelayanan kesehatan rujukan yang terdiri atas 25 Rumah Sakit Pemerintah, 1 Rumah Sakit Khusus Jiwa, 28 Rumah Sakit Swasta, 209 Klinik Spesialis, 11 Klinik Utama dan 3 Balai Kesehatan yang berpartisipasi pada awal pelaksanaan program JKN. Langkah ini diharapkan dapat mempermudah masyarakat dalam mengakses fasilitas kesehatan. ${ }^{7}$

Walaupun pemerintah telah menyediakan fasilitas kesehatan tersebut, masih ada masalah yang menghambat proses terpenuhinya kebutuhan masyarakat akan kesehatan seperti puskesmas yang tidak mempunyai dokter umum dan gigi (4\%), dimana dari 22 puskesmas dan 62 puskesmas pembantu yang ada di kota Padang, tenaga medis yang tersedia hanya 35 dokter umum dan 52 dokter gigi. Kemampuan puskesmas untuk mendiagnosa 144 jenis penyakit umum masih banyak dibawah 90\%, serta terbatasnya aksesbilitas terhadap pelayanan kesehatan juga menjadi masalah yang menghambat proses terpenuhinya kebutuhan masyarakat akan kesehatan. ${ }^{7}$ Oleh karena itu, JKN dalam pelaksanaannya menerapkan sistem rujukan berjenjang dari pelayanan kesehatan tingkat pertama ke pelayanan kesehatan tingkat kedua untuk mengatasi masalah tersebut.

Sehubungan dengan telah terlaksananya Jaminan Kesehatan Nasional (JKN) yang diselenggarakan melalui Badan Penyelenggara Jaminan Sosial (BPJS) maka peneliti berkeinginan mengadakan penelitian tentang perbandingan kunjungan pasien per kasus di pelayanan kesehatan gigi lanjutan pada rumah sakit di kota Padang ditinjau dari pemanfaatan sistem Jaminan Kesehatan Nasional (JKN). Rumah sakit yang dipilih oleh peneliti adalah rumah sakit terdiri dari Rumah Sakit Yos Sudarso 
Padang sebagai rumah sakit swasta dan Rumah Sakit Umum Daerah Padang sebagai rumah sakit pemerintah yang menangani pelayanan kesehatan tingkat lanjutan. Rumah Sakit Yos Sudarso Padang merupakan rumah sakit swasta dengan tipe $\mathrm{C}$ yang telah melaksanakan program BPJS dan Rumah Sakit Umum Daerah Padang merupakan rumah sakit pemerintah dengan tipe $\mathrm{C}$ yang telah melaksanakan program BPJS. Diharapkan dengan pemilihan 2 sampel ini, dapat mewakili rumah sakit lain di kota Padang dalam penelitian ini.

\section{METODE}

Jenis penelitian yang dilakukan adalah deskriptif dengan pendekatan kualitatif. Penelitian dilakukan di poli klinik gigi dan mulut Rumah Sakit Yos Sudarso Padang, Rumah Sakit Umum Daerah Padang, serta puskesmas di kota Padang. Populasi dan sampel dalam penelitian ini adalah pasien di poli klinik gigi dan mulut di Rumah Sakit Yos Sudarso Padang dan Rumah Sakit Umum Daerah Padang yang menggunakan fasilitas rujukan dan memanfaatkan sistem pembiayaan kesehatan JKN pada tahun 2014 dan pasien yang tidak memanfaatkan sistem pembiayaan nasional pada tahun 2013. Pengumpulan data yang digunakan dalam penelitian ini meliputi data primer dan wawancara terbuka dengan informan. Data yang diperoleh dari data primer meliputi jumlah kunjungan pasien rujukan, jenis penyakit dan tindakan pelayanan di poli gigi dan mulut di rumah sakit kota Padang. Sedangkan Data yang diperoleh dari wawancara yang ditanyakan kepada responden dengan pertanyaan yang mengacu kepada pandangan responden terhadap kebijakan JKN tentang sistem rujukan yang dilakukan/ dialami oleh responden. Dimana pedoman wawancara disusun dengan komponen sebagai berikut :

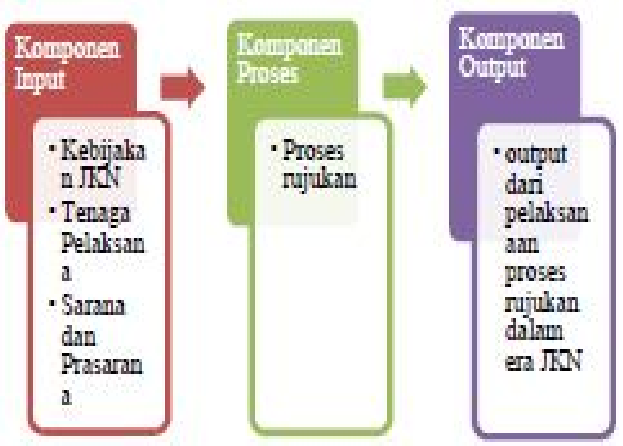

Data dikumpulkan langsung dari data primer Rumah Sakit Yos Sudarso Padang dan Rumah Sakit Umum Daerah Padang. dan langsung dari responden dan dilakukan sendiri oleh peneliti. Peneliti melakukan pengumpulan data primer dari rumah sakit dari januari 2013 sampai desember 2014. Kemudian dilakukan pengelompokkan data berdasarkan sistem pembiayaan, tingkat kunjungan dan jenis pelayanan serta tindakan yang dilaksanakan di rumah sakit tersebut. 
Peneliti kemudian melakukan pendekatan kepada responden (dokter gigi di pelayanan kesehatan tingkat pertama, dokter gigi di pelayanan kesehatan tingkat kedua dan masyarakat yang memanfaatkan sistem rujukan berjenjang dengan menggunakan sistem pembiayaan JKN). Responden diminta kesediaannya untuk berpartisipasi dalam penelitian. Kemudian responden dipersilahkan menjawab pertanyaan sesuai pandangan responden terhadap kebijakan JKN tentang sistem rujukan yang dilakukan/ dialami oleh responden dan terakhir dilakukan penggelompokkan data berdasarkan pandangan dari responden

HASIL

Berdasarkan data yang diperoleh Jumlah kunjungan pasien di poli gigi Rumah Sakit Yos Sudarso kota Padang pada tahun 2014 meningkat jika dibandingkan dengan tahun sebelumnya. Jumlah kunjungan pasien yang menggunakan JKN pada tahun 2014 lebih banyak daripada pasien yang menggunakan asuransi pada tahun 2013 yaitu sebesar 1570 kunjungan atau sebesar 45,1\% dibandingkan dengan tahun sebelumnya sebesar $44 \%$. Sedangkan jumlah kunjungan pasien poli gigi di Rumah Sakit Umum Daerah dr. Rasidin kota Padang pada tahun 2014 mengalami penurunan jika dibandingkan dengan tahun 2013 yang belum menjalankan kebijakan JKN. Namun jumlah kunjungan pasien yang menggunakan JKN pada tahun 2014 lebih banyak daripada pasien yang menggunakan asuransi (Askes, Jamkesmas, Jamkesda, dan lain-lain) pada tahun 2013 yaitu sebesar 53,75\% dibandingkan dengan tahun sebelumnya yaitu sebesar 50,22\%.

Kasus kesehatan gigi dan mulut yang paling banyak muncul pasca penyelenggaraan JKN adalah penyakit pulpa yaitu sebesar 54\% dari seluruh kasus di Rumah Sakit Yos Sudarso dan 49\% dari seluruh kasus di Rumah Sakit Umum Daerah dr. Rasidin kota Padang. Tindakan pelayanan kesehatan gigi dan mulut yang paling banyak muncul pasca penyelenggaraan $\mathrm{JKN}$ adalah penambalan yaitu sebesar 40,63\% dari seluruh tindakan di Rumah Sakit Umum Daerah dr. Rasidin kota Padang.

\section{PEMBAHASAN}

Dari data yang diperoleh dari Rumah Sakit Yos Sudarso kota Padang dapat dilihat bahwa pasien kunjungan mengalami peningkatan dari tahun 2013 ke tahun 2014. Peningkatan pasien disebabkan karena lokasi rumah sakit yang cukup strategis sehingga pasien lebih memilih untuk dirujuk ke rumah sakit tersebut. Jumlah kunjungan pasien 
di poli gigi Rumah Sakit Yos Sudarso yang menggunakan JKN pada tahun 2014 lebih banyak daripada pasien yang menggunakan asuransi pada tahun 2013 yaitu sebesar 1570 kunjungan atau sebesar 45,1\% dibandingkan dengan tahun sebelumnya sebesar $44 \%$.

Sedangkan di Rumah Sakit Umum Daerah dr. Rasidin kota Padang diketahui bahwa tingkat kunjungan pasien menurun dari tahun 2013 ke tahun 2014. Hal ini disebabkan karena sulitnya masyarakat untuk memperoleh akses transportasi ke rumah sakit tersebut dan lokasi rumah sakit tersebut yang sulit dijangkau. Namun jumlah kunjungan pasien yang menggunakan JKN pada tahun 2014 lebih banyak daripada pasien yang menggunakan asuransi (Askes, Jamkesmas, Jamkesda, dan lain-lain) pada tahun 2013 yaitu sebesar 53,75\% dibandingkan dengan tahun sebelumnya yaitu sebesar 50,22\%.

\section{KESIMPULAN}

Jumlah kunjungan pasien di poli gigi Rumah Sakit Yos Sudarso per kasus secara keseluruhan mengalami peningkatan dari tahun sebelum diadakannya JKN dan jumlah kunjungan pasien di poli gigi Rumah Sakit Umum Daerah dr. Rasidin Padang per kasus secara keseluruhan mengalami penurunan dari tahun sebelum diadakannya JKN.
Tindakan pelayanan kesehatan gigi dan mulut yang paling banyak muncul pasca penyelenggaraan $\mathrm{JKN}$ adalah penambalan yaitu sebesar $40,63 \%$ dari seluruh tindakan di Rumah Sakit Umum Daerah dr. Rasidin kota Padang.

Peningkatan tingkat rujukan pasien di poli gigi pada Rumah Sakit Yos Sudarso Kota Padang disebabkan karena kurangnya tenaga ahli, sarana dan prasarana di pelayanan kesehatan tingkat dasar serta kebijakan JKN untuk merujuk beberapa kasus tertentu yang tidak bisa ditangani di pelayanan kesehatan tingkat pertama. Sedangkan penurunan jumlah kunjungan pasien di poli gigi Rumah Sakit Umum Daerah dr. Rasidin Padang disebabkan karena sulitnya transportasi dan jauhnya lokasi rumah sakit. Kebijakan JKN juga menyebabkan penurunan tingkat kunjungan pasien karena pasien diperbolehkan memilih tempat pelayanan kesehatan yang diinginkan.

\section{KEPUSTAKAAN}

1. Perserikat Bangsa-Bangsa. 1948. Deklarasi Universal Hak-Hak Azazi Manusia Pasal 25 Ayat (1).

2. World Health Assembly. 2005.Fifty-eight world health assembly : Resolution and decisions. Palais des Nations, Genewa, Switzerland. May 16-25.

3. Undang - Undang Republik Indonesia No. 36 tahun 2009 tentang kesehatan. Lembaran Negara RI tahun 2009, No. 144, Tambahan Lembaran Negara RI, Nomor 5063. Sekretariat Negara. Jakarta. 
4. Peraturan Presiden Republik Indonesia No. 72 tahun 2012 tentang sistem kesehatan nasional. Sekretariat Negara. Jakarta.

5. Peraturan Badan Penyelenggara Jaminan Sosial No. 1 tahun 2014 tentang penyelenggaraan jaminan kesehatan. Sekretariat Negara. Jakarta.

6. Undang - Undang Republik Indonesia No. 40 tahun 2004 tentang rumah sakit. Sekretariat Negara. Jakarta.

7. Dinas Kesehatan Sumatera Barat. 2014. Bahan Publikasi Kunjungan Dirjen Pengendalian Penyakit dan Penyehatan Lingkungan ke Sumatera Barat. Padang. Sumatera Barat. Badan Penyelenggara Jaminan Sosial Kesehatan Republik Indonesia. 